\title{
GBV-C/HIV co-infected patients from AIDS Center Prague have higher CD4 cell counts and probably better quality of life
}

\author{
V Aster*1, J Konig ${ }^{2}$, H Rozsypal ${ }^{1}$, L Machala ${ }^{3}$, O Urbankova ${ }^{4}$ and M Stankova ${ }^{1}$
}

Address: ${ }^{1}$ Teaching Hospital Na Bulovce/3-rd Department of Infectious and Tropical Disesases, 1-st Medical Faculty, Charles University, Prague, Czech Republic, ${ }^{2}$ Vidia Diagnostika, Clinical Laboratory, Prague, Czech Republic, ${ }^{3}$ Teaching Hospital Na Bulovce/1-st Dept. of Infectious Diseases, 2-nd Medical Faculty, Charles University, Prague, Czech Republic and ${ }^{4}$ Teaching Hospital Na Bulovce, Prague, Czech Republic

* Corresponding author

from Ninth International Congress on Drug Therapy in HIV Infection

Glasgow, UK. 9-13 November 2008

Published: 10 November 2008

Journal of the International AIDS Society 2008, I I (SuppI I):P295 doi:I0.I I86/ I758-2652-I I-SI-P295

This abstract is available from: http://www.jiasociety.org/content/I I/SI/P295

(c) 2008 Aster et al; licensee BioMed Central Ltd.

\section{Purpose of the study}

To determine the prevalence of GBV-C/HGV (HGV) infection in HIV-infected patients, to assess the possible influence of HGV on the course of HIV infection by assessment of immunological and virological markers of progression of HIV infection, and to carry out a preliminary investigation on the effect of HGV infection on quality of life in HIV-infected patients.

\section{Methods}

Serum samples of $329 \mathrm{HIV}$-infected patients were investigated at the AIDS Center of the Teaching Hospital $\mathrm{Na}$ Bulovce, Prague, from 2002-2005. The aim was to assess the presence of markers of HGV infection by semiquantitative HGV PCR evaluation and anti-HGV antibodies by ELISA testing. HIV viral load and CD4 count were tested concurrently. The Spearman's test was used to rule out the correlation of CD4 count and HIV viral load on HGV infection. In a pilot study, $37 \mathrm{HIV}$-infected patients tested on markers of HGV infection, were evaluated for the quality of life by the SEIQoL and Life Satisfaction Questionnaire (LSQ) during 2007. We compared 13 (35.1\%) HGVinfected patients and $26(64.9 \%)$ patients without recent HGV infection.

\section{Summary of results}

107 (32.5\%) patients were positive on PCR HGV, 123 (37.4\%) patients were positive on anti-HGV-ELISA, and $12(3.6 \%)$ were positive on both markers. Both patients with positive PCR HGV and with positive anti-HGV had higher CD4 count. This fact was more significant in patients without HAART. No statistically significant effect of HIV viral load on HGV viremia or anti-HGV levels was observed. Average values in SEIQoL were 7.17 in HGVpositive and 5.93 in HGV-negative patients. LSQ values were 242.23 in HGV-positive and 233.88 in HGV-negative patients.

\section{Conclusion}

No relationship between HGV infection and HIV viral load was observed. Patients with present or past HGV infection had higher CD4 count. This relation was more apparent in patients without HAART therapy. Our results are comparable with results of other studies, showing beneficial effect of HGV infection on CD4 count in HIVinfected patients. On QoL, there is a trend showing that HGV co-infected patients tend to experience better quality of life measured by SEIQoL and LSQ than those without HGV co-infection.

\section{Acknowledgements}

The study is funded by the grant $\mathrm{Nr} / 9288-3$ from the Internal Grant Agency of the Ministry of Health of the Czech Republic. 